J. Dairy Sci. 92:3306-3318

doi:10.3168/jds.2008-1889

(c) American Dairy Science Association, 2009.

\title{
Effect of abomasal glucose infusion on splanchnic amino acid metabolism in periparturient dairy cows
}

\author{
M. Larsen and N. B. Kristensen ${ }^{1}$ \\ Department of Animal Health, Welfare and Nutrition, Faculty of Agricultural Sciences, Aarhus University, DK-8830 Tjele, Denmark
}

\begin{abstract}
Six Holstein cows fitted with ruminal cannulas and permanent indwelling catheters in the portal vein, hepatic vein, mesenteric vein, and an artery were used to study the effects of abomasal glucose infusion on splanchnic AA metabolism. The experimental design was a split plot, with cow as the whole plot, treatment as the whole-plot factor and days in milk (DIM) as the subplot factor. Cows were assigned to 1 of 2 treatments: control or infusion of $1,500 \mathrm{~g} / \mathrm{d}$ of glucose into the abomasum from the day of calving to 29 DIM. Cows were sampled prepartum and at 4, 15, and 29 DIM. Postpartum dry matter intake increased at a lower rate with infusion compared with the control. Arterial concentrations of all essential AA (EAA) were lower with infusion compared with the control. Net portal fluxes of His, Ile, Leu, Lys, Met, Phe, Thr, Val, Ala, Pro, Ser, and Tyr were lower with infusion compared with the control and the net portal fluxes of these AA showed positive correlations with dry matter intake, whereas the net portal fluxes of Asp, Glu, and Gln were unaffected by treatment. Net hepatic fluxes of EAA were not affected by treatment but increased as lactation progressed with both treatments. On a net basis, all EAA were removed by the liver prepartum and at 4 DIM, whereas Met, Phe, and Thr were the only EAA being removed at 29 DIM. Except for Ala, AA removed by the liver might be used primarily for noncatabolic processes, as exemplified by the $16 \%$ of hepatic Gly uptake accounted for as urinary hippurate. The measured hepatic uptake of glucogenic precursors (glucogenic AA, volatile fatty acids, lactate, and glycerol) accounted for 50 to $90 \%$ of the hepatic release of glucose. The hepatic urea output accounted for more than $100 \%$ of the hepatic ureagenic precursor uptake, indicating that the glucogenic precursors unaccounted for are nonnitrogen-containing compounds. In conclusion, an increased exogenous glucose supply to
\end{abstract}

Received November 11, 2008.

Accepted March 8, 2009.

${ }^{1}$ Corresponding author: nbk@agrsci.dk the small intestine did not seem to affect the amount of EAA and non-EAA available for peripheral tissues in early lactation, and the study did not indicate an AAsparing effect of small intestinal glucose absorption. In periparturient dairy cows, hepatic catabolism of AA was not driven by the increased whole-body demand for glucose, and Ala was the only AA that contributed substantially to hepatic gluconeogenesis. In very early lactation, the supply of EAA might be of greater concern than the supply of glucogenic substrates.

Key words: dairy cow, transition, amino acid, gluconeogenesis

\section{INTRODUCTION}

The transition from being a pregnant, nonlactating cow to a lactating, nonpregnant cow represents a great challenge to adaptation of metabolism in the gut, liver, mammary gland, and other peripheral tissues. The whole-body glucose turnover is dramatically increased by the initiation of lactose synthesis in the mammary gland, and it is assumed that propionate availability from ruminal fermentation is insufficient to fuel the hepatic gluconeogenesis in very early lactation, leading to increased catabolism of glucogenic AA (Danfær et al., 1995; Drackley et al., 2001). The hepatic demand for AA is further increased by an increased hepatic protein synthesis in the very first days after calving (Bell, 1995) and it has been suggested that the increased hepatic demand for AA in the first few days after calving might be covered by mobilization from a labile protein reserve in skeletal muscles (Bell, 1995; Drackley et al., 2001). Reynolds et al. (2003) found no evidence for an increased contribution of AA other than Ala to hepatic gluconeogenesis at $1.5 \mathrm{wk}$ postpartum; however, that does not preclude a substantial contribution of AA to hepatic gluconeogenesis in the very first days of lactation.

To increase the utilization of AA for milk protein synthesis, it is important to know whether the catabolism of AA in gut and hepatic tissues is obligatory in its nature or whether it can be manipulated by nutrition. Increased absorption of glucose from the small intestine has been speculated to enhance the efficiency with which 
AA are transferred from the intestinal lumen to the blood because the enterocytes might metabolize more glucose and spare AA (Nocek and Tamminga, 1991; Knowlton et al., 1998). Likewise, an increased supply of exogenous glucose could be partly compensated for by a decrease in hepatic gluconeogenesis, further sparing AA. Even though quantitative data on splanchnic metabolism of AA is increasingly available for dairy cows (Bach et al., 2000; Berthiaume et al., 2006), data on splanchnic AA metabolism in transition cows and on the effects of increased exogenous glucose supply are very limited.

We hypothesized that increased absorption of glucose from the small intestine in dairy cows would 1) decrease catabolism of AA in portal-drained viscera (PDV) and liver, and 2) decrease the utilization of AA in hepatic gluconeogenesis in early lactation. The objectives of the present study were to measure the effects of abomasal glucose infusion on splanchnic metabolism of AA in periparturient dairy cows and to evaluate hepatic mass balances of glucogenic carbon and ureagenic nitrogen.

\section{MATERIALS AND METHODS}

The present experiment complied with Danish Ministry of Justice Law No. 382 (June 10, 1987), Act No. 726 (September 9, 1993), concerning experiments with animals and care of experimental animals.

\section{Animals, Design, and Samplings}

A detailed description of the experiment was provided in a preceding paper (Larsen and Kristensen, 2009). Briefly, 6 ruminally cannulated Danish Holstein second-lactation cows catheterized in the major splanchnic vessels were used in a split-plot design with cow as the whole plot, treatment as the wholeplot factor, and DIM as the subplot factor. Cows were randomly assigned to 1 of 2 treatments: No infusion (control treatment) or continuous abomasal infusion of $1,500 \mathrm{~g} / \mathrm{d}$ of glucose from the day of calving (infusion treatment). Cows were sampled prepartum $(12 \pm 6 \mathrm{~d})$ before the initiation of treatments and postpartum at 4,15 , and 29 DIM. The same rations (nonlactation and lactation) were fed with both treatments and were fed in equally sized meals at 8-h intervals. Eight hourly sample sets of arterial, portal vein, and hepatic vein blood were obtained beginning $30 \mathrm{~min}$ before feeding at $0800 \mathrm{~h}$. Splanchnic blood plasma flows were determined by downstream dilution of $p$-aminohippuric acid infused $(36.4 \pm 1.3 \mathrm{mmol} / \mathrm{h})$ into a mesenteric vein. Milk yield and feed intake were recorded daily. Milk was sampled on sampling days and rations were sampled weekly.

\section{Analytical Procedures}

Heparinized plasma samples were analyzed for AA and urea by GC-MS according to the isotope dilution method described by Calder et al. (1999). A working AA standard was prepared from a commercial AA mixture (AAS18; Sigma-Aldrich Denmark A/S, Brøndby, Denmark) with added glutamine (L-glutamine 99\%, final concentration $400 \mu M$; Acros, Geel, Belgium), and urea (final concentration 7,500 $\mu M$; Merck, Darmstadt, Germany). The internal standard was made from a $\left[\mathrm{U}_{-}{ }^{13} \mathrm{C} / \mathrm{U}_{-}{ }^{15} \mathrm{~N}\right]$ cell free AA mixture (CNLM-6696-1; Cambridge Isotope Laboratories Inc., Andover, MA) with added $\left[{ }^{15} \mathrm{~N}_{2}\right]$ urea (no. 316830; Campro Scientific GmbH, Berlin, Germany). The essential AA (EAA) analyzed were His, Ile, Leu, Lys, Met, Phe, Thr, and Val; and the non-EAA analyzed were Ala, Asp, Cys, Gln, Glu, Gly, Pro, Ser, and Tyr. The isotope dilution method was not validated for Arg, Asn, and Trp.

The plasma concentrations of ammonia (EDTA plasma) and glycerol (heparinized plasma) were determined using enzymatic assays (AM 1015 and GY 105, respectively; Randox Laboratories Ltd., Crumlin, UK) adapted for use on a Cobas Mira autoanalyzer (Triolab A/S, Brøndby, Denmark). Concentrations of VFA and total protein were determined in heparinized plasma samples pooled within cow and DIM. Plasma VFA was determined by GC according to Kristensen (2000), coupled with a mass spectrometer as detector. Total protein was measured using the biuret reaction endpoint method (ABX Pentra Total Protein CP; Horiba ABX, Montpellier, France) adapted for use on a Cobas Mira autoanalyzer.

\section{Calculations and Statistical Procedures}

The ammonia concentration in whole blood was set equal to the plasma concentration, whereas the whole blood concentration of urea was obtained by dividing the plasma concentration by 1.09 (Røjen et al., 2008). The whole blood concentrations of VFA were obtained from plasma concentrations by correcting for a $45 \%$ dilution space in erythrocytes (Kristensen, 2000). Calculation of net portal fluxes, net hepatic fluxes, and hepatic extraction ratios of metabolites was performed as described by Kristensen et al. (2007). The maximal contribution (\%) of precursors to the net hepatic glucose or urea release was calculated as $(-s \times$ net hepatic flux of precursor/net hepatic flux of glucose or urea) $\times$ 100. The stoichiometric relationship between precursor and product, $s$, was set to 0.5 for all glucogenic precursors and for ureagenic precursors other than Gln and Lys $(s=1.0)$, and His $(s=1.5)$. All measured AA 
except for Leu and Lys were considered glucogenic. Secretion of EAA in milk protein was calculated by using tabulated values for content in skim milk powder ( $\mathrm{g} /$ kg of protein): His: 28.7; Ile: 57.1; Leu: 100.1; Lys: 78.7; Met: 24.7; Phe: 48.3; Thr: 44.5; Val: 67.2 (Misciattelli et al., 2002).

Data were analyzed according to the split-plot design, where whole plot (cow within treatment) was considered as a random factor, using the MIXED procedure (SAS Institute Inc., Cary, NC). Data on arterial variables and metabolite fluxes in nonpooled samples were analyzed by using a model including the fixed effects of treatment, DIM, and sampling time (time), and the possible interactions. Time within cow by DIM was considered as a repeated measure and was analyzed using an autoregressive order 1 covariance structure, because this covariance structure was generally found to fit well to the present type of time series. Data from pooled plasma samples were analyzed by using a reduced model excluding the fixed effect of time. There were missing observations for the hepatic variables (1 missing observation with the prepartum control, 4 DIM control, 29 DIM control, and 29 DIM infusion; 2 missing observations with the 15 DIM control). Therefore, least squares means \pm standard errors of the means are presented and the actual standard errors of the means are specified in the tables. Fisher's least significant differences test was used to test if the prepartum control to the 4 DIM control differed from the prepartum infusion to the 4 DIM infusion (named $P_{\text {trans } x \text { trt }}$ in tables). Fisher's protected least significant differences test was used to separate treatment means within DIM, and to separate prepartum from 4, 15 and 29 DIM, respectively, in cases with no effect of treatment. Significance was declared at $P \leq 0.05$ and tendencies were considered at $0.05<P \leq 0.10$. Pearson correlation analysis was conducted between DMI and net portal fluxes of metabolites.

\section{RESULTS}

From calving to 29 DIM, voluntary DMI increased at a lower rate $(P=0.05)$ with infusion compared with the control, and the overall treatment means were 10.7 and $16.9 \mathrm{~kg} / \mathrm{d}$, respectively. There was an interaction between treatment and DIM for milk and protein yield $(P$ $=0.04$ and $P=0.07$, respectively), reflecting markedly reduced rates of increase from approximately 4 DIM with infusion compared with the control. The overall treatment means for milk yield were 26.7 and 19.7 for the control and infusion, respectively. The concentration of protein in milk was not affected $(P=0.38)$ by treatment, but decreased $(P<0.01)$ from 41 to $32 \mathrm{~g} /$ $\mathrm{kg}$ between 4 and 15 DIM.

\section{Arterial Variables}

There was an interaction $(P=0.01$; Table 1$)$ between treatment and DIM for the arterial concentration of total EAA, reflecting an increasing concentration with increasing DIM with the control, compared with a lower and not increasing concentration with infusion. The markedly different postpartum patterns for the arterial concentrations of EAA between treatments were apparent for most of the individual EAA except for His and Thr. The arterial concentrations of total non-EAA and concentrations of the individual non-EAA, except for Ala and Pro, were not affected $(P=0.15$ to $P=0.97)$ by treatment, but increased $(P<0.01$ to $P=0.10)$ with increasing DIM with both treatments. For the arterial concentrations of Ala and Pro, there were interactions $(P=0.03$ and $P=0.06$, respectively) between treatment and DIM, reflecting greater and increasing concentrations as lactation progressed with the control compared with lower and not increasing concentrations with infusion.

The arterial plasma concentration of total protein decreased $(P=0.02)$ more from prepartum to 4 DIM with infusion compared with the control. The arterial content of total protein had reached the prepartum level by 15 DIM with both treatments. The arterial concentration of glycerol tended $(P=0.10)$ to increase less from prepartum to 4 DIM with infusion compared with the control. Postpartum, arterial glycerol decreased $(P$ $<0.01)$ with increasing DIM with both treatments. The arterial concentration of urea was lower $(P=0.02)$ with infusion compared with the control. The arterial concentration of ammonia increased from prepartum to 4 DIM with both treatments $(P=0.05)$. Postpartum, arterial ammonia decreased $(P=0.01)$ with increasing DIM from the increased level at 4 DIM, and was not affected by treatment $(P=0.14)$. The arterial concentration of acetate decreased from prepartum to 4 DIM with both treatments $(P<0.01)$. Postpartum, the arterial concentration of acetate tended $(P=0.07)$ to increase at a greater rate with the control compared with infusion. The arterial concentrations of VFA other than acetate and caproate increased $(P=0.02$ to $P=$ 0.10) with increasing DIM.

\section{Net Portal Fluxes}

Except for Gln and prepartum Glu, all net portal fluxes of individual AA were positive (Table 2). Treatment did not affect $(P=0.13$ to $P=0.95)$ prepartum to 4 DIM differences for any of the measured net portal fluxes of AA. The net portal flux of total EAA tended $(P=0.06)$ to be greater with the control compared with infusion, and increased $(P=0.01)$ with increasing DIM 
with both treatments. This pattern was observed for all individual EAA other than Met, where an interaction $(P=0.03)$ was observed between treatment and DIM, reflecting a greater rate of increase with the control compared with infusion. The ratio of EAA secretion in milk protein to the net portal flux of EAA was not affected by treatment $(P=0.36$; Figure 1$)$, but tended to decrease from 2.1 to 1.3 between 4 and 29 DIM ( $P$ $=0.10)$. There was a tendency toward an interaction $(P=0.07)$ between treatment and DIM for the net portal flux of total non-EAA, reflecting a greater rate of increase with the control compared with infusion. The net portal fluxes of individual non-EAA other than Ala, Pro, and Ser were not affected by treatment but increased with increasing DIM. The net portal fluxes of Ala, Pro, and Ser were greater $(P=0.04$ to $P=0.07)$ with the control compared with infusion, and increased $(P<0.01$ to $P=0.03)$ with increasing DIM with both treatments. The net portal fluxes of individual AA per kilogram of DMI were unaffected $(P \geq 0.19$; data not shown) by treatment.

The net portal flux of glycerol tended to increase more $(P=0.06)$ from prepartum to 4 DIM with the control compared with infusion. Postpartum, the net portal flux of glycerol had decreased $(P=0.04)$ to the prepartum level by 15 DIM with both treatments. Analysis for correlations between net portal fluxes (Table 2) and voluntary DMI showed strong positive correlations for Ile, Leu, Lys, Met, Phe, Thr, Val, Ala, Pro, Ser, Tyr, all VFA, and ammonia $(P<0.0001 ; \mathrm{r}=$ 0.72 to $\mathrm{r}=0.91$ ), weaker positive correlations for Asp, Glu, Gly, and His $(P<0.01 ; \mathrm{r}=0.52$ to $\mathrm{r}=0.64)$, no correlations for Cys, Gln, and glycerol $(P \geq 0.18)$, and a strong negative correlation for urea $(P<0.0001 ; \mathrm{r}=$ $-0.79)$.

\section{Net Hepatic Fluxes}

The net hepatic fluxes of all individual EAA were negative (net uptake) both prepartum and at 4 DIM (Table 3). Postpartum, the net hepatic fluxes of branched-chain AA (Leu, Ile, and Val), His, and Lys had changed to positive values (net release) at 29 DIM. There was an interaction $(P=0.03$ to $P=0.07)$ between treatment and DIM for the net hepatic fluxes of Ile, Lys, and Val, reflecting greater rates of change from uptake at 4 DIM to release at 29 DIM with the control compared with infusion. The net hepatic fluxes of His and Leu were not affected $(P \geq 0.50)$ by treatment, but changed $(P=0.02$ to $P=0.07)$ from net uptake at 4 DIM to net release at $29 \mathrm{DIM}$. Decreasing $(P=0.01$ to $P=0.08)$ net hepatic uptake with increasing DIM was observed for Met and Thr. The net hepatic uptake of Phe was affected neither by treatment $(P=0.32)$ nor by DIM $(P=0.23)$. Net hepatic releases were observed for Asp, Gln, and Glu, whereas net hepatic uptakes were observed for all other non-EAA. The changes in net hepatic fluxes of individual non-EAA from prepartum to 4 DIM were not affected $(P=0.12$ to $P=0.88)$ by treatment. The net hepatic uptake of Ala, Cys, Gly, Pro, and Ser was affected neither by treatment $(P=$ 0.13 to $P=0.63)$ nor by DIM $(P=0.41$ to $P=0.99)$. The net hepatic release of Asp, Gln, and Glu increased $(P=0.01$ to $P=0.05)$ as lactation progressed with both treatments.

The net hepatic uptake of glycerol tended $(P=0.06)$ to increase more from prepartum to 4 DIM with the control compared with infusion. The change in net hepatic uptake of ammonia from prepartum to 4 DIM was affected $(P=0.05)$ by treatment, reflecting a decreased uptake with infusion at $4 \mathrm{DIM}$. The corresponding net hepatic release of urea mirrored the pattern of net hepatic uptake of ammonia. Postpartum, there was an interaction $(P<0.01)$ between treatment and DIM for the net hepatic uptake of ammonia, reflecting increasing uptake with the control as lactation progressed compared with an unchanged uptake with infusion. Postpartum, the net hepatic release of urea reflected the pattern of net hepatic uptake of ammonia with both treatments. Postpartum, there was an interaction $(P<0.01$ to $P=0.07)$ between treatment and DIM for the net hepatic uptake of propionate, isobutyrate, butyrate, and isovalerate, reflecting increasing rates of uptake with the control compared with infusion.

\section{Hepatic Extraction of $A A$}

The hepatic extraction ratios of individual EAA were in the range of 0.02 to 0.19 both prepartum and 4 DIM (Table 4). Postpartum, the hepatic extraction ratios of individual EAA decreased $(P=0.01$ to $P=0.15)$ between 4 and 15 DIM to be close to zero $(-0.05$ to 0.05 ; negative extraction ratio $=$ net hepatic release) with both treatments. Postpartum, the hepatic extraction ratio of non-EAA differed substantially between the individual AA; for example, Ala and Gly were extracted in substantial amounts compared with a substantial release of Glu.

\section{Hepatic Uptake of Glucogenic and Ureagenic Precursors}

The maximal contribution of glucogenic EAA, nonEAA, glucogenic VFA, lactate, and glycerol to net hepatic release of glucose was not affected by treatment either from prepartum to 4 DIM $(P=0.18$ to $P=0.87$; Table 5$)$ or postpartum $(P=0.13$ to $P=$ 0.98). In descending order, propionate, lactate, Ala, 
Table 2. Net portal fluxes of essential AA (EAA), branched-chain AA (BCAA), non-EAA, glycerol, urea, ammonia, and VFA (mmol/h)

\begin{tabular}{|c|c|c|c|c|c|c|c|c|c|c|c|c|c|c|}
\hline \multirow[b]{2}{*}{ Item } & \multicolumn{2}{|c|}{$\begin{array}{c}\text { Prepartum } \\
\text { treatment group }\end{array}$} & \multirow[b]{2}{*}{$P_{\text {trans } \times \text { trt }}^{2}$} & \multicolumn{2}{|c|}{4 DIM treatment } & \multicolumn{2}{|c|}{15 DIM treatment } & \multicolumn{2}{|c|}{29 DIM treatment } & \multirow[b]{2}{*}{$\mathrm{SEM}^{3}$} & \multicolumn{4}{|c|}{$P$-value ${ }^{4}$} \\
\hline & $\mathrm{C}$ & I & & $\mathrm{C}$ & I & $\mathrm{C}$ & I & $\mathrm{C}$ & I & & Trt & DIM & Time $^{5}$ & Trt $\times$ DIM \\
\hline \multicolumn{15}{|l|}{ Plasma fluxes } \\
\hline EAA & 54 & 51 & 0.32 & 85 & 50 & 161 & $63^{*}$ & 175 & $91^{*}$ & 21 & 0.06 & 0.01 & 0.84 & 0.22 \\
\hline $\mathrm{BCAA}^{\mathrm{a}}$ & 24 & 25 & 0.32 & 41 & 26 & 84 & 33 & 86 & 47 & 12 & 0.08 & 0.01 & 0.31 & 0.21 \\
\hline His & 1.8 & 1.4 & 0.16 & 7.0 & $2.0 \dagger$ & 6.3 & 2.0 & 5.8 & 2.6 & 1.6 & 0.01 & 0.99 & 0.07 & 0.87 \\
\hline $\mathrm{Ile}^{\mathrm{a}}$ & 6.5 & 7.0 & 0.29 & 12 & 7.4 & 25 & $10^{*}$ & 25 & $14 \dagger$ & 3 & 0.07 & 0.01 & 0.63 & 0.22 \\
\hline Leu & 10 & 10 & 0.26 & 16 & 10 & 34 & $13^{*}$ & 35 & $19 \dagger$ & 4 & 0.08 & $<0.01$ & 0.30 & 0.13 \\
\hline Lys & 11 & 10 & 0.24 & 15 & 8.5 & 27 & $12 \dagger$ & 29 & $16 \dagger$ & 4 & 0.12 & $<0.01$ & 0.66 & 0.27 \\
\hline Met $^{\mathrm{ab}}$ & 2.7 & 2.7 & 0.28 & 4.1 & 2.5 & 9.4 & $3.0^{* *}$ & 8.3 & $4.5^{*}$ & 1.0 & 0.03 & $<0.01$ & 0.07 & 0.03 \\
\hline Phe & 6.0 & 6.1 & 0.16 & 10 & 6.2 & 19 & $7.6^{* *}$ & 19 & $11^{*}$ & 2 & 0.05 & $<0.01$ & 0.11 & 0.10 \\
\hline Thr & 6.9 & 5.6 & 0.36 & 10 & 5.0 & 22 & $4.8^{*}$ & 23 & $10^{*}$ & 3.3 & 0.07 & 0.01 & 0.78 & 0.11 \\
\hline Val & 7.6 & 7.8 & 0.43 & 13 & 8.5 & 25 & $9.4^{*}$ & 26 & $15 \dagger$ & 4.1 & 0.11 & 0.02 & 0.13 & 0.28 \\
\hline Non-EAA & 50 & 30 & 0.78 & 65 & 35 & 128 & $35^{*}$ & 169 & $54^{*}$ & 23 & 0.06 & 0.01 & 0.99 & 0.07 \\
\hline $\mathrm{Ala}^{\mathrm{c}}$ & 20 & 21 & 0.29 & 27 & 17 & 58 & $25^{*}$ & 60 & $33 \dagger$ & 7 & 0.07 & $<0.01$ & 0.02 & 0.16 \\
\hline Asp & 1.2 & 1.0 & 0.73 & 0.9 & 0.6 & 1.8 & 1.8 & 2.3 & 1.8 & 0.3 & 0.42 & $<0.01$ & 0.22 & 0.62 \\
\hline Cys & 2.0 & 2.9 & 0.76 & 1.6 & 1.2 & 1.0 & -1.0 & 2.3 & 0.5 & 2.1 & 0.63 & 0.78 & 0.68 & 0.91 \\
\hline $\mathrm{Gln}^{\mathrm{c}}$ & -7.0 & -25 & 0.15 & -18 & -13 & -20 & -32 & -10 & -33 & 8 & 0.28 & 0.64 & $>0.99$ & 0.28 \\
\hline Glu & -4.0 & -2.3 & 0.62 & 2.4 & 2.7 & 3.4 & 2.0 & 5.2 & 2.1 & 1.7 & 0.38 & 0.75 & 0.49 & 0.53 \\
\hline Gly & 12 & 10 & 0.52 & 13 & 6 & 27 & 15 & 32 & 17 & 6 & 0.20 & 0.01 & 0.86 & 0.64 \\
\hline Pro ${ }^{d}$ & 4.4 & 4.0 & 0.13 & 8.0 & 3.2 & 14.5 & $4.0^{* *}$ & 12.9 & $6.8 \dagger$ & 1.8 & 0.04 & 0.03 & 0.48 & 0.17 \\
\hline $\mathrm{Ser}^{\mathrm{e}}$ & 14 & 13 & 0.22 & 20 & 11 & 32 & $13^{*}$ & 38 & $17^{*}$ & 4 & 0.05 & $<0.01$ & 0.68 & 0.16 \\
\hline $\mathrm{Tyr}^{\mathrm{f}}$ & 7.8 & 5.5 & 0.95 & 8.9 & 6.3 & 18 & $7.6^{*}$ & 19 & $8.6 \dagger$ & 2.9 & 0.10 & 0.04 & 0.40 & 0.24 \\
\hline Total AA & 104 & 80 & 0.48 & 154 & 86 & 289 & $97^{*}$ & 344 & $144^{*}$ & 42 & $\begin{array}{l}0.10 \\
0.05\end{array}$ & 0.04 & $\begin{array}{l}0.40 \\
0.96\end{array}$ & 0.15 \\
\hline Glycerol & 1.4 & 2.3 & 0.06 & 6.6 & 3.2 & 1.4 & 1.7 & 4.1 & 1.8 & 1.4 & 0.23 & 0.04 & 0.30 & 0.38 \\
\hline \multicolumn{15}{|c|}{ Whole blood fluxes } \\
\hline Urea & -103 & -80 & 0.49 & -108 & -66 & -174 & $-62^{* *}$ & -175 & $-86^{* *}$ & 16 & 0.02 & 0.01 & 0.31 & 0.06 \\
\hline Ammonia & 355 & 349 & 0.12 & 367 & 230 & 502 & $216^{* *}$ & 628 & $306^{* *}$ & 47 & 0.02 & $<0.01$ & 0.05 & 0.09 \\
\hline Acetate & 1,475 & 1,160 & 0.35 & 1,413 & 814 & 2,318 & $912^{* *}$ & 2,312 & $1,133^{*}$ & 200 & 0.02 & $<0.01$ & - & 0.02 \\
\hline Propionate & 513 & 413 & 0.17 & 612 & 290 & 1,089 & $415^{* *}$ & 1,030 & $440^{*}$ & 108 & 0.03 & $<0.01$ & - & 0.06 \\
\hline Isobutyrate & 19 & 14 & 0.56 & 16 & 9 & 24 & $10^{*}$ & 28 & $13^{* *}$ & 3 & 0.03 & $<0.01$ & - & 0.09 \\
\hline Butyrate & 90 & 73 & 0.16 & 130 & 65 & 212 & $91 *$ & 243 & $98^{* *}$ & 23 & 0.03 & $<0.01$ & - & 0.10 \\
\hline Isovalerate & 9 & 6 & 0.34 & 8 & 3 & 13 & $4^{* *}$ & 16 & $6^{* *}$ & 2 & 0.03 & $<0.01$ & - & 0.08 \\
\hline Valerate & 14 & 13 & 0.07 & 24 & $10 \dagger$ & 37 & $15^{*}$ & 41 & $18^{* *}$ & 5 & 0.03 & 0.02 & - & 0.37 \\
\hline Caproate & 11 & 8 & 0.19 & 19 & $7 \dagger$ & 13 & 10 & 30 & $14^{*}$ & 4 & 0.05 & 0.06 & - & 0.29 \\
\hline \multicolumn{15}{|c|}{${ }^{\mathrm{a}}$ Tendency toward a treatment $($ Trt $) \times$ time interaction $(P \leq 0.10)$. } \\
\hline \multicolumn{15}{|c|}{ bendency toward a DIM $\times$ time interaction $(P \leq 0.10)$. } \\
\hline \multicolumn{15}{|c|}{${ }^{\mathrm{c}}$ Trt $\times$ DIM $\times$ time interaction $(P \leq 0.05)$} \\
\hline \multicolumn{15}{|c|}{${ }^{\mathrm{d}}$ Trt $\times$ time interaction $(P \leq 0.05)$} \\
\hline \multicolumn{15}{|c|}{${ }^{\mathrm{e}} \mathrm{DIM} \times$ time interaction $(P \leq 0.05)$} \\
\hline \multicolumn{15}{|c|}{${ }^{\mathrm{f}}$ Tendency to Trt $\times$ DIM $\times$ time interaction $(P \leq 0.10)$. } \\
\hline \multicolumn{15}{|c|}{${ }^{1}$ Treatments were control $(\mathrm{C})$ or continuous infusion $(\mathrm{I})$ of $349 \pm 6 \mathrm{mmol} / \mathrm{h}$ of glucose $(1,500 \mathrm{~g} / \mathrm{d})$ into the abomasum from 1 to 29 DIM. } \\
\hline \multicolumn{15}{|c|}{${ }^{2}$ Fisher's LSD test for prepartum control to 4 DIM control to differ from prepartum infusion to 4 DIM infusion. } \\
\hline${ }^{3} \mathrm{n}=3$. & 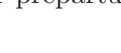 & 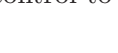 & & & & & & & & & & & & \\
\hline${ }^{4}$ Fixed effects & repartum & ervations & e excludec & from data & & & & & & & & & & \\
\hline${ }^{5}$ Time within & g day. & & & & & & & & & & & & & \\
\hline$\dagger P \leq 0.10 ; * 1$ & ${ }^{* *} P \leq 0$ & superscr & signify & ference & tween I & within & and row & & & & & & & \\
\hline
\end{tabular}



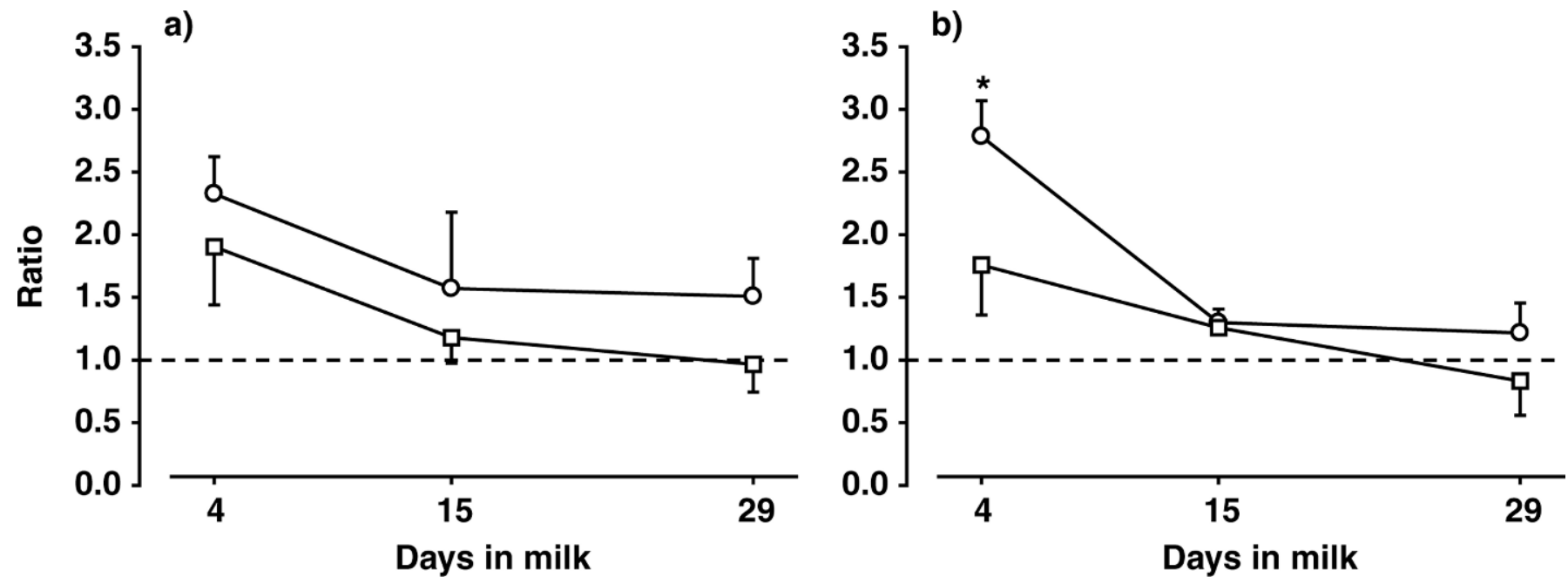

Figure 1. Ratio of essential AA secretion in milk protein to net portal (a) and net splanchnic (b) fluxes of essential AA in dairy cows with either no infusion ( $\square$, control) or continuous abomasal infusion of $349 \pm 6 \mathrm{mmol} / \mathrm{h}(1,500 \mathrm{~g} / \mathrm{d})$ of glucose $(\bigcirc$, infusion) from the day of calving. Each datum point is the mean of 3 observations \pm standard error. The ratio for net portal fluxes (a) was not affected $(P=0.36)$ by treatment, but tended to decrease from 2.1 to 1.3 between 4 and 29 DIM $(P=0.10)$. The ratio for net splanchnic fluxes (b) was greater with infusion at 4 DIM $(P=0.05)$ and decreased $(P<0.01)$ with increasing DIM.

and Gly had the greatest maximal contributions to net hepatic glucose release. The contribution of glucogenic EAA to the net hepatic glucose release was negligible (maximum 0 to $2.5 \%$ ), whereas the non-EAA contributed maximally approximately $10 \%$ to the net hepatic glucose release, largely accounted for by Ala and Gly uptake. The maximal contribution to the net hepatic glucose release of glucogenic EAA, Ala, Gly, and lactate was greatest at $4 \mathrm{DIM}$ and tended $(P=0.04$ to $P=0.10$ ) to decrease between 4 and 29 DIM. Overall, the hepatic uptake of glucogenic precursors accounted for maximally 50 to $90 \%$ of the hepatic release of glucose (Table 5). The absolute amount of hepatic glucose release not accounted for by precursor uptake increased as lactation progressed $(100 \mathrm{mmol} / \mathrm{h}$ prepartum and $300 \mathrm{mmol} / \mathrm{h}$ at $29 \mathrm{DIM})$.

On a net basis, ammonia nitrogen was the greatest contributor to net hepatic urea nitrogen release, with an average maximal contribution of $93 \pm 8 \%$ (Table 5 ). Essential AA contributed negligible amounts to the net hepatic urea release, as compared with the non-EAA. Of all AA, Ala and Gly were the greatest contributors to the net hepatic release of urea, in accordance with these being the greatest contributors to net hepatic glucose release. Overall, the measured hepatic extraction of ureagenic precursors accounted for 92 to $167 \%$ of the hepatic release of urea, with the highest maximal contributions being measured prepartum and at 4 DIM.

\section{DISCUSSION}

The observed effect of abomasal glucose infusion on DMI in the present study was greater than in postrumi- nal infusion studies conducted in established lactations (see Larsen and Kristensen, 2009). However, the present effect on DMI was quite similar to that obtained with the hyperinsulinemic-euglycemic clamp technique in periparturient cows (Leury et al., 2003), also inducing similar changes in circulating levels of glucose and insulin. Therefore, the lower DMI with the infusion treatment was most likely caused by an impairment of the endocrine cascade responsible for the metabolic adaptations in very early lactation, as discussed by Larsen and Kristensen (2009). However, it has to be recognized throughout the discussion that the treatment effect was confounded by the lower DMI with infusion.

\section{Metabolism of AA in the PDV}

The PDV metabolizes both EAA and non-EAA in substantial amounts, as indicated by portal recovery of 33 to $49 \%$ of the total AA disappearing from the small intestine of dairy cows (Berthiaume et al., 2001; Reynolds, 2006). In the present study, the net portal flux of total AA could account for $37 \pm 5 \%$ of the calculated dietary supply of metabolizable protein. Of the nonEAA, Asp, Gln, and Glu are extensively metabolized by the PDV (Berthiaume et al., 2001; Reynolds, 2006), and accordingly, we found net portal fluxes of Asp and Glu that did not differ from zero and negative net portal fluxes of Gln.

Few data are available on the effects of a small intestinal glucose supply on PDV metabolism of AA in ruminants. In ewes, Freetly et al. (2007) found the net portal flux of a range of AA to be unaffected by 
Table 3. Net hepatic fluxes of essential AA (EAA), branched-chain AA (BCAA), non-EAA, glycerol, urea, ammonia, and VFA (mmol/h)

\begin{tabular}{|c|c|c|c|c|c|c|c|c|c|c|c|c|c|c|}
\hline \multirow[b]{2}{*}{ Item } & \multicolumn{2}{|c|}{$\begin{array}{l}\text { Prepartum } \\
\text { treatment group }\end{array}$} & \multirow[b]{2}{*}{$P_{\text {trans } \times \text { trt }}^{2}$} & \multicolumn{2}{|c|}{4 DIM treatment } & \multicolumn{2}{|c|}{15 DIM treatment } & \multicolumn{2}{|c|}{29 DIM treatment } & \multirow[b]{2}{*}{$\mathrm{SEM}^{3}$} & \multicolumn{4}{|c|}{$P$-value ${ }^{4}$} \\
\hline & $\mathrm{C}$ & I & & $\mathrm{C}$ & I & $\mathrm{C}$ & I & $\mathrm{C}$ & I & & Trt & DIM & Time $^{5}$ & Trt $\times$ DIM \\
\hline \multicolumn{15}{|l|}{ Plasma fluxes } \\
\hline $\mathrm{EAA}^{\mathrm{a}}$ & -36 & -6 & 0.94 & -55 & -23 & -4 & 23 & 25 & -2 & 24 & 0.69 & 0.05 & 0.12 & 0.28 \\
\hline BCAA & -19 & 1.0 & 0.55 & -17 & -6.2 & 4.2 & 16 & 27 & 6.4 & 10 & 0.88 & 0.01 & 0.24 & 0.12 \\
\hline His & -1.3 & -0.1 & 0.81 & -5.7 & -3.7 & -1.8 & 0.9 & 2.2 & 1.5 & 1.8 & 0.50 & 0.02 & 0.25 & 0.51 \\
\hline Ile & -6.3 & 0.7 & 0.24 & -4.3 & -2.4 & 1.8 & 4.3 & 8.6 & 1.9 & 3.7 & $>0.99$ & $<0.01$ & 0.03 & 0.07 \\
\hline Leu & -6.4 & -0.2 & 0.67 & -5.4 & -2.1 & 3.0 & 5.5 & 7.7 & 1.6 & 4.5 & 0.89 & 0.07 & 0.63 & 0.45 \\
\hline Lys $^{\mathrm{b}}$ & -3.2 & -0.8 & 0.48 & -7.1 & -1.5 & 6.0 & 3.8 & 10.4 & 0.8 & 3.3 & 0.79 & $<0.01$ & 0.06 & 0.03 \\
\hline Met & -2.1 & -0.9 & 0.81 & -4.0 & -2.4 & -0.8 & 0.3 & -0.5 & -1.5 & 1.2 & 0.67 & 0.01 & 0.41 & 0.46 \\
\hline $\mathrm{Phe}^{\mathrm{c}}$ & -5.7 & -4.2 & 0.52 & -8.5 & -4.8 & -6.1 & -0.4 & -5.3 & -4.8 & 2.1 & 0.32 & 0.23 & 0.14 & 0.51 \\
\hline Thr & -5.0 & -1.0 & 0.70 & -9.9 & -3.8 & -0.9 & 3.0 & -1.1 & -3.8 & 4.1 & 0.66 & 0.08 & 0.73 & 0.42 \\
\hline Val & -5.8 & 0.6 & 0.70 & -6.2 & -1.7 & -0.1 & 6.2 & 10.5 & 2.7 & 4.2 & 0.82 & $<0.01$ & 0.29 & 0.04 \\
\hline Non-EAA ${ }^{\mathrm{a}}$ & -56 & -37 & 0.52 & -156 & -91 & -70 & -3 & -94 & -93 & 38 & 0.26 & 0.14 & 0.34 & 0.73 \\
\hline Ala & -36 & -33 & 0.12 & -79 & -33 & -55 & -24 & -29 & -45 & 13 & 0.13 & 0.41 & 0.56 & 0.12 \\
\hline $\mathrm{Asp}^{\mathrm{a}}$ & 0.6 & 0.7 & 0.88 & 0.1 & 0.0 & 2.7 & 1.1 & 0.9 & 0.8 & 0.6 & 0.24 & 0.02 & $<0.01$ & 0.32 \\
\hline Cys & -1.7 & -1.2 & 0.47 & -4.6 & -0.4 & -6.3 & -0.3 & -2.8 & -1.8 & 2.6 & 0.15 & 0.99 & 0.22 & 0.67 \\
\hline Gln & 2.4 & 0.6 & 0.67 & -0.5 & 7.2 & 50 & 37 & 11 & 13 & 12 & 0.93 & 0.01 & 0.24 & 0.79 \\
\hline Glu & 44 & 33 & 0.86 & 30 & 23 & 53 & 46 & 43 & 55 & 11 & 0.86 & 0.05 & 0.56 & 0.46 \\
\hline $\mathrm{Gly}^{\mathrm{d}}$ & -37 & -23 & 0.76 & -78 & -57 & -74 & -51 & -54 & -78 & 12 & 0.63 & 0.76 & 0.10 & 0.16 \\
\hline Pro & -5.5 & -3.8 & 0.74 & -8.7 & -5.6 & -7.6 & -1.8 & -2.9 & -5.9 & 2.4 & 0.55 & 0.32 & 0.03 & 0.25 \\
\hline $\mathrm{Ser}^{\mathrm{c}}$ & -14 & -6.1 & 0.73 & -18 & -16 & -29 & -7.1 & -33 & -16 & 10 & 0.34 & 0.76 & 0.30 & 0.47 \\
\hline Tyr & -7.1 & -4.9 & 0.40 & -4.8 & -6.4 & -6.2 & -1.2 & -14 & -7.4 & 2.6 & 0.36 & 0.06 & 0.62 & 0.16 \\
\hline Total $\mathrm{AA}^{\mathrm{a}}$ & -92 & -43 & 0.65 & -211 & -114 & -73 & 19 & -69 & -98 & 60 & 0.47 & 0.15 & 0.28 & 0.59 \\
\hline \multirow{2}{*}{\multicolumn{15}{|c|}{ Whole blood fluxes }} \\
\hline & & & & & & & & & & & & & & \\
\hline Urea & 177 & 216 & 0.01 & 283 & $151^{*}$ & 260 & $127^{*}$ & 402 & $184^{* *}$ & 33 & $<0.01$ & 0.06 & 0.41 & 0.40 \\
\hline Ammonia & -348 & -371 & 0.05 & -399 & -269 & -275 & -226 & -591 & $-319^{*}$ & 43 & 0.07 & $<0.01$ & 0.42 & $<0.01$ \\
\hline Acetate & 369 & 131 & 0.99 & 499 & 263 & 449 & 316 & 240 & 414 & 240 & 0.67 & 0.97 & - & 0.67 \\
\hline Propionate & -477 & -391 & 0.30 & -494 & -267 & -815 & $-351^{*}$ & -935 & $-403^{*}$ & 99 & 0.06 & 0.01 & - & 0.07 \\
\hline Isobutyrate & -18 & -13 & 0.04 & -16 & $-8^{*}$ & -17 & $-8^{* *}$ & -25 & $-12^{* *}$ & 1 & 0.01 & $<0.01$ & - & $<0.01$ \\
\hline Butyrate & -74 & -62 & 0.10 & -107 & -52 & -160 & $-51^{*}$ & -210 & $-81^{* *}$ & 19 & 0.04 & $<0.01$ & - & 0.02 \\
\hline Isovalerate & -7 & -6 & 0.02 & -7 & $-3 \dagger$ & -9 & $-2^{*}$ & -14 & $-5^{* *}$ & 1 & 0.02 & $<0.01$ & - & $<0.01$ \\
\hline Valerate & -14 & -11 & 0.26 & -23 & -11 & -38 & -18 & -42 & -28 & 6 & 0.15 & 0.08 & - & 0.57 \\
\hline Caproate & -13 & -4 & 0.63 & -18 & -5 & -19 & -11 & -36 & -23 & 5 & 0.15 & 0.02 & - & 0.82 \\
\hline \multicolumn{15}{|c|}{${ }^{\mathrm{a}}$ Tendency toward a treatment $($ Trt $) \times$ DIM $\times$ time interaction $(P \leq 0.10)$. } \\
\hline \multicolumn{15}{|c|}{${ }^{\mathrm{b}}$ Trt $\times$ time interaction $(P \leq 0.05)$} \\
\hline \multicolumn{15}{|c|}{ 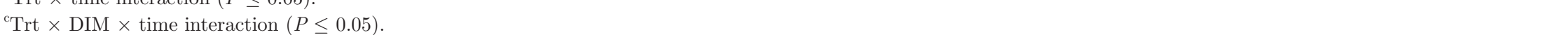 } \\
\hline \multicolumn{15}{|c|}{${ }^{\mathrm{d}}$ Tendency toward a DIM $\times$ time interaction $(P \leq 0.10)$. } \\
\hline \multirow{2}{*}{\multicolumn{15}{|c|}{$\begin{array}{l}{ }^{1} \text { Treatments were control }(\mathrm{C}) \text { or continuous infusion (I) of } 349 \pm 6 \mathrm{mmol} / \mathrm{h} \\
{ }^{2} \text { Fisher's LSD test for prepartum control to } 4 \text { DIM control to differ from pre }\end{array}$}} \\
\hline & & & & & & tum inf & ion to $4 \mathrm{I}$ & M infusic & & & & & & \\
\hline \multicolumn{15}{|c|}{${ }^{3} \mathrm{n}=2$. } \\
\hline \\
\hline \multirow{2}{*}{\multicolumn{15}{|c|}{${ }^{5}$ Time within sampling day. }} \\
\hline$\dagger P \leq 0.10 ; * I$ & ${ }^{* *} P \leq 0$ & & & & & & & & & & & & & \\
\hline
\end{tabular}


Table 4. Net hepatic extraction ratios of essential AA (EAA), branched-chain AA (BCAA), and non-EAA in transition cows ${ }^{1}$

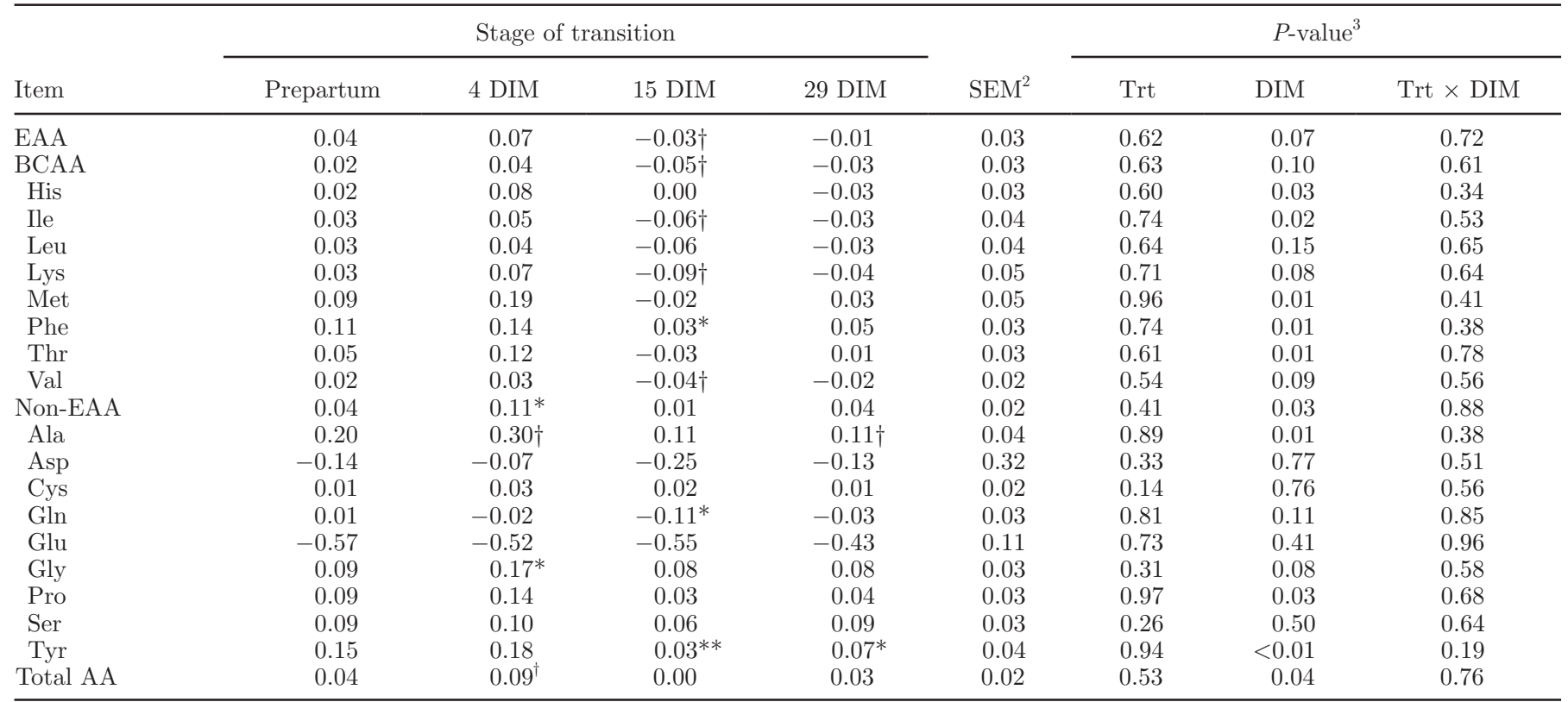

${ }^{1}$ The LSM for sampling days are shown because there were no effects of treatment. Treatments (Trt) were control or continuous infusion of 349 $\pm 6 \mathrm{mmol} / \mathrm{h}$ of glucose $(1,500 \mathrm{~g} / \mathrm{d})$ into the abomasum from 1 to 29 DIM.

${ }^{2} \mathrm{n}=5$.

${ }^{3}$ Fixed effects when prepartum observations are excluded from the data set.

$\dagger P \leq 0.10 ;{ }^{*} P \leq 0.05 ;{ }^{*} P \leq 0.01$ : superscripts signify LSM postpartum to differ from prepartum within rows.

abomasal infusion of glucose, and in dairy cows, Meijer et al. (1997) found the bioavailability of Gln and Leu to be unaffected by 2 levels of starch supplied to the duodenum. In the present study, the net portal fluxes of Asp, Gln, and Glu, all know as major substrates for energy metabolism in enterocytes (Reynolds, 2006), were not increased with infusion. The unexpected lower DMI with infusion and the concomitant lower intestinal AA supply precludes strong conclusions on the effect of exogenous glucose supply on PDV AA catabolism. However, contrary to our initial hypothesis, our data do not indicate an AA-sparing effect in the PDV by increased exogenous glucose supplied to the small intestine.

\section{Hepatic Metabolism of AA}

It has been suggested that supply of metabolizable protein in excess of the requirement would be catabolized by the liver, which implies that the arterial concentration of AA is the major determinant of hepatic extraction (Lobley and Lapierre, 2003; Reynolds, 2002). The observed net hepatic extraction of all EAA both prepartum and at 4 DIM could therefore indicate that EAA were supplied in excess; however, the metabolic fate of the extracted EAA might differ between the 2 different physiological stages. Prepartum, the dietary supply of metabolizable protein exceeded the calculated requirement by $12 \%$ based on Danish recommendations for nutrient allowances, and the excess AA were probably catabolized by the liver. In contrast, the extracted EAA in very early lactation were most likely used for hepatic synthesis of constitutive and export proteins, as indicated by the findings of an increased fractional rate of protein synthesis in very early lactation (Bell, 1995). Figure 1 illustrates that particularly at 4 DIM, both net portal and net splanchnic (sum of net portal and net hepatic) supplies of free EAA were insufficient to account for the milk protein output of EAA with both treatments. Even though the splanchnic tissues supplied an increasing part of the EAA secreted in milk protein as lactation progressed, the present data indicate that it takes some weeks before the net portal flux of free EAA can account for the milk protein output of EAA. The fact that both the net portal and net splanchnic fluxes of EAA are unable to account for the milk protein output of EAA in very early lactation shows that 1) the dietary supply of EAA was insufficient, and 2) the liver was not fully compensating for the deficient dietary supply by breakdown of proteins. Therefore, milk protein secretion in very early lactation must have been sustained by an interorgan transfer of AA not involving the liver, for example, tissue mobilization, regression of uterine tissue, and perhaps secretion 
Table 5. Net hepatic uptake of precursors as maximal contributions (\%) to net hepatic release of glucose or urea

\begin{tabular}{|c|c|c|c|c|c|c|c|c|c|c|c|c|c|}
\hline \multirow[b]{2}{*}{ Item } & \multicolumn{2}{|c|}{ Prepartum treatment group ${ }^{1}$} & \multirow[b]{2}{*}{$P_{\text {trans } \times \text { trt }}^{2}$} & \multicolumn{2}{|c|}{4 DIM treatment } & \multicolumn{2}{|c|}{15 DIM treatment } & \multicolumn{2}{|c|}{29 DIM treatment } & \multirow[b]{2}{*}{$\mathrm{SEM}^{3}$} & \multicolumn{3}{|c|}{$P$-value ${ }^{4}$} \\
\hline & $\mathrm{C}$ & I & & $\mathrm{C}$ & I & $\mathrm{C}$ & I & $\mathrm{C}$ & I & & Trt & DIM & Trt $\times$ DIM \\
\hline \multicolumn{14}{|c|}{$\%$ of net glucose release ${ }^{5}$} \\
\hline Glucogenic EAA ${ }^{6}$ & 2.6 & 0.8 & 0.53 & 2.6 & 2.2 & 0.4 & -1.4 & 0.2 & 0.3 & 1.5 & 0.73 & 0.09 & 0.75 \\
\hline His & 0.2 & 0.0 & 0.75 & 0.4 & 0.3 & 0.1 & -0.1 & -0.1 & 0.0 & 0.2 & 0.96 & 0.15 & 0.81 \\
\hline Ile & 0.6 & -0.0 & - & 0.3 & 0.3 & -0.2 & -0.4 & - & -0.1 & 0.4 & 0.82 & 0.19 & 0.56 \\
\hline Met & 0.2 & 0.1 & 0.65 & 0.3 & 0.3 & 0.0 & -0.0 & 0.0 & 0.1 & 0.1 & 0.94 & 0.08 & 0.86 \\
\hline Phe & 0.6 & 0.5 & 0.73 & 0.5 & 0.5 & 0.4 & 0.0 & 0.3 & 0.3 & 0.2 & 0.71 & 0.02 & 0.28 \\
\hline Thr & 0.5 & 0.2 & 0.83 & 0.7 & 0.5 & 0.1 & -0.3 & 0.0 & 0.3 & 0.4 & 0.86 & 0.19 & 0.72 \\
\hline Val & 0.5 & 0.0 & - & 0.4 & 0.3 & 0.0 & -0.6 & - & -0.1 & 0.4 & 0.53 & 0.32 & 0.55 \\
\hline Non-EAA ${ }^{7}$ & 9.8 & 7.9 & 0.76 & 12.5 & 12.2 & 10.2 & 8.4 & 6.2 & 10.2 & 2.8 & 0.93 & 0.25 & 0.72 \\
\hline Ala & 3.4 & 3.7 & 0.25 & 5.1 & 3.7 & 2.7 & 2.3 & 1.5 & 2.9 & 1.0 & 0.84 & 0.10 & 0.31 \\
\hline Asp & -0.1 & -0.1 & - & -0.0 & -0.0 & - & - & - & -0.1 & 0.05 & - & - & - \\
\hline Cys & 0.2 & 0.2 & 0.38 & 0.3 & 0.1 & 0.4 & -0.0 & 0.1 & 0.1 & 0.1 & 0.13 & 0.94 & 0.46 \\
\hline Gln & -0.1 & -0.2 & - & -0.3 & -0.7 & - & - & -0.8 & -0.8 & 0.9 & 0.64 & 0.56 & 0.84 \\
\hline Glu & - & — & - & - & - & - & - & - & — & - & - & - & - \\
\hline Gly & 3.6 & 2.7 & 0.18 & 5.1 & 6.2 & 4.0 & 5.0 & 2.8 & 5.1 & 0.9 & 0.36 & 0.04 & 0.48 \\
\hline Pro & 0.6 & 0.4 & 0.68 & 0.6 & 0.6 & 0.4 & 0.2 & 0.1 & 0.4 & 0.2 & 0.97 & 0.28 & 0.63 \\
\hline Ser & 1.5 & 0.7 & 0.43 & 1.3 & 1.7 & 1.6 & 0.6 & 1.7 & 1.3 & 0.8 & 0.75 & 0.75 & 0.68 \\
\hline Tyr & 0.7 & 0.5 & 0.24 & 0.4 & 0.7 & 0.4 & 0.2 & 0.7 & 0.5 & 0.3 & 0.98 & 0.47 & 0.48 \\
\hline Propionate & 50.8 & 44.0 & 0.87 & 35.7 & 27.6 & 52.6 & 33.8 & 48.8 & 29.3 & 8.7 & 0.27 & 0.25 & 0.51 \\
\hline Isobutyrate & 1.9 & 1.4 & 0.56 & 1.1 & 0.9 & 1.1 & 0.9 & 1.3 & 0.9 & 0.3 & 0.29 & 0.75 & 0.75 \\
\hline Valerate & $\begin{array}{l}1.5 \\
1.5\end{array}$ & $\begin{array}{l}1.4 \\
1.1\end{array}$ & 0.81 & $\begin{array}{l}1.1 \\
1.7\end{array}$ & 1.1 & $\begin{array}{l}1.1 \\
2.4\end{array}$ & 1.6 & 2.2 & 2.2 & 0.6 & 0.63 & 0.52 & 0.77 \\
\hline L-Lactate & 20.4 & 15.8 & 0.24 & 33.5 & 16.6 & 9.8 & 7.4 & 15.2 & 5.3 & 6.7 & 0.21 & 0.06 & 0.53 \\
\hline Glvcerol & 1.1 & 1.3 & 0.20 & 2.7 & 1.4 & 0.2 & 1.1 & 0.8 & 0.4 & 0.7 & 0.66 & 0.19 & 0.43 \\
\hline Total & 88.2 & 71.9 & 0.47 & 89.8 & 62.0 & 73.4 & 51.3 & 74.6 & 46.8 & 10.7 & 0.15 & 0.28 & 0.94 \\
\hline \multicolumn{14}{|l|}{$\%$ of net urea release } \\
\hline Ammonia & 109 & 93.6 & 0.04 & 79.9 & 111 & 62.6 & 94.9 & 80.6 & 95.9 & 15.5 & 0.21 & 0.54 & 0.86 \\
\hline Ala & 11.4 & 8.0 & 0.45 & 13.6 & 12.7 & 8.7 & 8.8 & 6.2 & 12.4 & 3.1 & 0.76 & 0.04 & 0.08 \\
\hline Other AA than Ala & 36.3 & 9.0 & 0.30 & 29.8 & 45.5 & 23.3 & -1.9 & 14.5 & 17.1 & 22.8 & 0.84 & 0.19 & 0.59 \\
\hline Total & 156 & 110 & 0.02 & 117 & 167 & 91.6 & 98.9 & 104 & 120 & 30.0 & 0.69 & 0.06 & 0.64 \\
\hline
\end{tabular}

${ }^{1}$ Treatments (Trt) were control (C) or continuous infusion (I) of $349 \pm 6 \mathrm{mmol} / \mathrm{h}$ of glucose (1,500 g/d) into the abomasum from 1 to $29 \mathrm{DIM}$.

2Fisher's LSD test for prepartum control to 4 DIM control to differ from prepartum infusion to 4 DIM infusion.

坚. ${ }^{3} \mathrm{n}=2$.

() ${ }^{4}$ Fixed effects when prepartum observations are excluded from the data set.

도을 $\quad{ }^{5}$ For net hepatic fluxes, see Larsen and Kristensen (2009).

$\quad{ }^{6}$ Excluding Lys and Leu, and Trt $\times$ DIM combinations where the net hepatic flux of an AA were larger than 0 (LSM, $t$-test, $\left.P \leq 0.10\right)$.

${ }^{7}$ Excluding Trt $\times$ DIM combinations where the net hepatic flux of an AA was larger than 0 (LSM, $t$-test, $P \leq 0.10$ ). 
of proteins synthesized in extramammary tissues. For example, the secretion of Ig in milk around parturition (Schanbacher and Smith, 1975) will, to some extent, explain the origin of protein not synthesized in the mammary gland.

At 4 DIM, the cows with the infusion treatment seemed to be more dependent on interorgan transfer of EAA than cows with the control treatment, as indicated by the greater ratio of EAA secretion in milk protein relative to net splanchnic supply (Figure 1b). The circulating levels of glucose and insulin were increased with infusion (Larsen and Kristensen, 2009), most likely resulting in less mobilization of fat and protein from body reserves. Insulin has normally been thought to decrease milk protein production because of an increased competition for AA by tissues other than the mammary gland (Griinari et al., 1997). However, in studies investigating the role of insulin on milk protein production with the hyperinsulinemic-euglycemic clamp technique with cows in midlactation, milk protein production has been found to be increased by insulin in association with decreased plasma concentrations of EAA (Griinari et al., 1997; Mackle et al., 2000). In these studies, the reduction of DMI with insulin infusion was similar to that observed in postruminal glucose infusion studies conducted in established lactations, and thus, was not as dramatic as observed in periparturient cows. Griinari et al. (1997) found increased plasma concentration of IGF-I in association with the insulin infusion, and they speculated that the IGF system could be responsible for the changes in milk protein production. In contrast, the arterial concentration of IGF-I was not changed with infusion in the present study (Larsen and Kristensen, 2009), as might be expected from the increased insulin concentration. However, the influence of insulin on milk protein synthesis is unclear, and a comparison of effects obtained in established lactations with the effects observed in periparturient cows is probably difficult, as indicated by the relatively greater effect of insulin on voluntary DMI observed in periparturient cows. Another interesting observation with cows receiving the infusion at 4 DIM was the lower plasma protein content compared with the control, which could reflect impaired liver function caused by a lower availability of EAA for hepatic synthesis of export proteins. However, Raggio et al. (2007) showed that hepatic synthesis of export proteins was maintained during a low supply of metabolizable protein, which suggests that the present decrease in plasma protein content was due to a different partitioning of nutrients and not impaired liver function.

The hepatic metabolism of individual non-EAA showed much greater variation than was observed for the EAA, suggesting that some of the non-EAA partici- pate in a diversity of metabolic functions in addition to being utilized for protein synthesis (Danfær, 1994; Danfær et al., 1995). Hepatic metabolism of Ala and Gly will be discussed because the extraction rates of these non-EAA were the highest of all non-EAA. The extraction of Ala was similar to that observed in other studies with dairy cows (Lomax and Baird, 1983; Reynolds et al., 2003; Berthiaume et al., 2006), reflecting the role of Ala as an interorgan transporter of amino groups from catabolized AA in the PDV and peripheral tissues by transamination with pyruvate. The hepatic extraction of Ala was especially high in very early lactation, which indicates an increased mobilization of AA from extrahepatic tissues.

Hepatic conjugation of benzoate with Gly to hippurate will contribute to the nonglucogenic use of Gly. The urinary excretion of Gly in hippurate in the present study could account for $16 \pm 3 \%$ of the hepatic uptake of Gly, as estimated by using measured urinary concentration of hippurate (average $17.5 \pm 2.4 \mathrm{mM}$ ) and an estimate for diuresis of $1 \mathrm{~L} / \mathrm{kg}$ of DMI (Murphy, 1992). Further, Gly is used for the synthesis of the bile salt glycocholate (Noble, 1978). Thus, the amount of Gly used for the synthesis of a range of compounds in the liver seemed to account for a substantial part of the Gly removed by the liver, and suggests that only a minor part of Gly removed was used for gluconeogenesis.

Overall, the lower DMI with infusion precludes a strong conclusion on the effect of an exogenous supply of glucose on hepatic metabolism; however, contrary to our initial hypothesis, the hepatic output of AA did not seem to be increased by an increased glucose supply. Alanine was the only AA being catabolized in substantial amounts by the liver in early lactation, because the hepatic synthesis of proteins and other AA-containing compounds seemed to account for most of the other AA removed by the liver.

\section{Hepatic Removal of Glucogenic Precursors}

In dairy cows, AA have been found to contribute from 2 to $40 \%$ to the net hepatic release of glucose by using different experimental techniques and applying several assumptions (Bergman and Heitmann, 1978; Danfær et al., 1995). The calculated maximal contributions of AA to the net hepatic release of glucose in the present study indicated that, among all the AA measured, Ala is the only quantitatively important AA precursor for gluconeogenesis. This is supported by the findings of Bergman and Heitmann (1978), who estimated the contribution of AA to hepatic glucose release in sheep both as maximal contributions based on net hepatic flux and by $\left[{ }^{14} \mathrm{C}\right]$ enrichment of glucose with infusion of $\left[{ }^{14} \mathrm{C}\right]$-labeled AA. From isotope transfer to glucose, 
Bergman and Heitmann (1978) observed low rates of transfer of AA other than Ala to glucose, whereas the calculated maximal contributions of AA to hepatic release of glucose were similar to those obtained in the present study. In agreement with the data of Bergman and Heitmann (1978) on sheep, Reynolds et al. (2003) found no indication for a contribution of AA other than Ala to hepatic gluconeogenesis when calculating the hepatic balance of glucogenic carbon on an incremental basis in early-lactation dairy cows.

The amount of hepatic glucose release unaccounted for by propionate, lactate, and glycerol in the present study is within the previously observed range (Danfær et al., 1995; Reynolds et al., 2003), as also were the contributions of the individual glucogenic precursors. The observations at 4 DIM with the control are of particular interest, for which the recycling of glucose carbon to the liver (sum of Ala, lactate, and glycerol) represented approximately $40 \%$ of the hepatic glucose release, which emphasizes the importance of this recycling in very early lactation, when feed intake has increased only slightly. It has become common belief that AA are significant substrates for hepatic gluconeogenesis in early lactation, covering the observed lack of glucogenic precursors (Danfær et al., 1995; Drackley et al., 2001). However, hepatic metabolism of the AA measured in the present study suggests that free plasma AA, except for Ala, do not contribute substantially to hepatic gluconeogenesis at any time during the first 4 wk of lactation. Thus, other compounds must have contributed substantially to net hepatic glucose release to cover the lack of glucogenic precursors.

Amino acids in circulating peptides and the free plasma AA not analyzed in the present study could potentially have contributed to hepatic gluconeogenesis. However, the hepatic removal of ureagenic precursors accounted for 92 to $167 \%$ (Table 5) of the hepatic release of urea, indicating that the lacking glucogenic precursors most likely would be found in nonnitrogen compounds. In fact, the hepatic balance of ureagenic precursor uptake and urea release comes close to $100 \%$ for all the treatment $\times$ DIM combinations if Ala is the only AA included, which further indicates that the AA removed are predominantly utilized in noncatabolic pathways. Small intestinal digestion of ruminal microbes will supply several substances that eventually could enter gluconeogenesis. For example, the breakdown of microbial DNA-RNA provides deoxyriboseribose from the nucleosides. Carbon from purines is primarily excreted in urine as allantoin and uric acid; however, pyrimidine bases are likely to be extensively degraded in the liver (Bender, 1985) and will potentially be a significant source of carbon to the ruminant liver. The $\beta$-oxidation of odd-chain fatty acids $\left(\mathrm{C}_{15}\right.$ and $\left.\mathrm{C}_{17}\right)$ from the bacterial cell wall will probably be a minor source of propionyl-coenzyme A. In addition, pyruvate (Baird et al., 1980) and keto-acids from catabolism of the branched-chain AA in extrahepatic tissues could contribute to hepatic gluconeogenesis.

The present data support the previously mentioned concept of the liver as catabolizing only AA supplied in excess of the requirement (Reynolds, 2002; Lobley and Lapierre, 2003), and further indicates that hepatic catabolism of AA is not stimulated by the whole-body demand for glucose because the increased whole-body demand for glucose with the control did not increase the contribution of AA to gluconeogenesis.

Overall, Ala seemed to be the only AA that contributed substantially to hepatic gluconeogenesis, and most markedly at 4 DIM with the control. With the control cows, the hepatic uptake of glucogenic precursors generally did not account for more than 70 to $90 \%$ of the hepatic release of glucose, whereas the hepatic uptake of ureagenic precursors accounted for 90 to $160 \%$ of the hepatic release of urea. Therefore, hepatic catabolism of AA did not seem to be driven by the increased wholebody demand for glucose in periparturient dairy cows.

\section{CONCLUSIONS}

Abomasal infusion of glucose in periparturient dairy cows induced lower DMI, which precludes strong conclusions on the effects on splanchnic AA metabolism. However, the present data did not suggest an AA-sparing effect of increased exogenous supply of glucose in the PDV or liver tissues. Hepatic catabolism of AA did not seem to be increased in early-lactation dairy cows, and Ala seemed to be the only AA that contributed substantially to hepatic gluconeogenesis, irrespective of the glucogenic status and stage of transition. The present study suggests that the supply of essential AA might be of greater concern in very early lactation than the supply of glucogenic substrates, although uncertainties remain in defining the entire precursor pool for hepatic glucose release.

\section{ACKNOWLEDGMENTS}

We gratefully acknowledge Birgit H. Løth, Faculty of Agricultural Sciences, Aarhus University (Tjele, Denmark), for skillful and dedicated efforts in the laboratory. Funding was provided by the Danish Cattle Federation (Aarhus, Denmark) and the Faculty of Agricultural Sciences, Aarhus University (Tjele, Denmark). M. Larsen was supported by an Industrial $\mathrm{PhD}$ fellowship program under the Danish Ministry of Science, Technology and Innovation (Copenhagen, Denmark). The present fellowship was held by the Faculty of Life Sciences, 
University of Copenhagen (Frederiksberg, Denmark), the Institute for Agro Technology and Food Innovation (Aarhus, Denmark), and the Faculty of Agricultural Sciences, Aarhus University (Tjele, Denmark).

\section{REFERENCES}

Bach, A., G. B. Huntington, S. Calsamiglia, and M. D. Stern. 2000. Nitrogen metabolism of early lactation cows fed diets with two different levels of protein and different amino acid profiles. J. Dairy Sci. 83:2585-2595.

Baird, G. D., M. A. Lomax, H. W. Symonds, and S. R. Shaw. 1980. Net hepatic and splanchnic metabolism of lactate, pyruvate and propionate in dairy cows in vivo in relation to lactation and nutrient supply. Biochem. J. 186:47-57.

Bell, A. W. 1995. Regulation of organic nutrient metabolism during transition from late pregnancy to early lactation. J. Anim. Sci. 73:2804-2819.

Bender, D. 1985. Amino Acid Metabolism. John Wiley and Sons, Chichester, UK.

Bergman, E. N., and R. N. Heitmann. 1978. Metabolism of aminoacids by gut, liver, kidneys, and peripheral tissues. Fed. Proc. $37: 1228-1232$.

Berthiaume, R., P. Dubreuil, M. Stevenson, B. W. McBride, and H. Lapierre. 2001. Intestinal disappearance and mesenteric and portal appearance of amino acids in dairy cows fed ruminally protected methionine. J. Dairy Sci. 84:194-203.

Berthiaume, R., M. C. Thivierge, R. A. Patton, P. Dubreuil, M. Stevenson, B. W. McBride, and H. Lapierre. 2006. Effect of ruminally protected methionine on splanchnic metabolism of amino acids in lactating dairy cows. J. Dairy Sci. 89:1621-1634.

Calder, A. G., K. E. Garden, S. E. Anderson, and G. E. Lobley. 1999. Quantitation of blood and plasma amino acids using isotope dilution electron impact gas chromatography/mass spectrometry with $\mathrm{U}_{-}{ }^{13} \mathrm{C}$ amino acids as internal standards. Rapid Commun. Mass Spectrom. 13:2080-2083.

Danfær, A. 1994. Nutrient metabolism and utilization in the liver. Livest. Prod. Sci. 39:115-127.

Danfær, A., V. Tetens, and N. Agergaard. 1995. Review and an experimental study on the physiological and quantitative aspects of gluconeogenesis in lactating ruminants. Comp. Biochem. Physiol. B Biochem. Mol. Biol. 111:201-210.

Drackley, J. K., T. R. Overton, and G. N. Douglas. 2001. Adaptations of glucose and long-chain fatty acid metabolism in liver of dairy cows during the periparturient period. J. Dairy Sci. 84(E Suppl.):E100-E112

Freetly, H. C., C. Ferrell, and S. Archibeque. 2007. Net flux of amino acids across splanchnic tissues of ewes during abomasal protein and glucose infusion. Pages 337-338 in Energy and Protein Metabolism and Nutrition. I. Ortigues-Marty, ed. Wageningen Academic Publishers, Wageningen, the Netherlands.

Griinari, J. M., M. A. Mcguire, D. A. Dwyer, D. E. Bauman, D. M. Barbano, and W. A. House. 1997. The role of insulin in the regulation of milk protein synthesis in dairy cows. J. Dairy Sci. 80:2361-2371.

Knowlton, K. F., T. E. Dawson, B. P. Glenn, G. B. Huntington, and R. A. Erdman. 1998. Glucose metabolism and milk yield of cows infused abomasally or ruminally with starch. J. Dairy Sci. $81: 3248-3258$

Kristensen, N. B. 2000. Quantification of whole blood short-chain fatty acids by gas chromatographic determination of plasma 2-chloroethyl derivatives and correction for dilution space in erythrocytes. Acta Agric. Scand. Anim. Sci. 50:231-236.

Kristensen, N. B., A. Storm, B. M. L. Raun, B. A. Røjen, and D. L. Harmon. 2007. Metabolism of silage alcohols in lactating dairy cows. J. Dairy Sci. 90:1364-1377.

Larsen, M., and N. B. Kristensen. 2009. Effect of abomasal glucose infusion on splanchnic and whole body glucose metabolism in periparturient dairy cows. J. Dairy Sci. 92:1071-1083.

Leury, B. J., L. H. Baumgard, S. S. Block, N. Segoale, R. A. Ehrhardt, R. P. Rhoads, D. E. Bauman, A. W. Bell, and Y. R. Boisclair. 2003. Effect of insulin and growth hormone on plasma leptin in periparturient dairy cows. Am. J. Physiol. Regul. Integr. Comp. Physiol. 285:R1107-R1115.

Lobley, G. E., and H. Lapierre. 2003. Post-absorptive metabolism of amino acids. Pages 737-756 in Progress in Research on Energy and Protein Metabolism. W. B. Souffrant and C. C. Metges, ed. Wageningen Academic Publishers, Wageningen, the Netherlands.

Lomax, M. A., and G. D. Baird. 1983. Blood flow and nutrient exchange across the liver and gut of the dairy cow. Br. J. Nutr. 49:481-496.

Mackle, T. R., D. A. Dwyer, K. L. Ingvartsen, P. Y. Chouinard, D. A. Ross, and D. E. Bauman. 2000. Effects of insulin and postruminal supply of protein on use of amino acids by the mammary gland for milk protein synthesis. J. Dairy Sci. 83:93-105.

Meijer, G. A. L., V. Bontempo, A. M. Van Vuuren, and J. Van Der Meulen. 1997. Effect of starch on the bioavailability of glutamine and leucine in the dairy cow. J. Dairy Sci. 80:2143-2148.

Misciattelli, L., T. Hvelplund, M. R. Weisbjerg, J. Madsen, J. Møller, R. Thøgersen, and A. M. Kjeldsen. 2002. Fodermidlernes indhold af aminosyrer og aminosyrernes andel af AAT. Rep. No. 98. Danish Agric. Advisory Serv., Danish Cattle Fed., Aarhus, Denmark.

Murphy, M. R. 1992. Water metabolism of dairy cattle. J. Dairy Sci. 75:326-333.

Noble, R. C. 1978. Digestion, absorption and transport of lipids in ruminant animals. Prog. Lipid Res. 17:55-91.

Nocek, J. E., and S. Tamminga. 1991. Site of digestion of starch in the gastrointestinal tract of dairy cows and its effect on milk yield and composition. J. Dairy Sci. 74:3598-3629.

Raggio, G., G. E. Lobley, R. Berthiaume, D. Pellerin, G. Allard, P. Dubreuil, and H. Lapierre. 2007. Effect of protein supply on hepatic synthesis of plasma and constitutive proteins in lactating dairy cows. J. Dairy Sci. 90:352-359.

Reynolds, C. K. 2002. Economics of visceral energy metabolism in ruminants: Toll keeping or internal revenue service? J. Anim. Sci. 80(E Suppl. 2):E74-E84.

Reynolds, C. K. 2006. Splanchnic amino acid metabolism in ruminants. Pages 225-248 in Ruminant Physiology: Digestion, Metabolism and Impact of Nutrition on Gene Expression, Immunology and Stress. K. Sejrsen, T. Hvelplund, and M. O. Nielsen, ed. Wageningen Academic Publishers, Wageningen, the Netherlands.

Reynolds, C. K., P. C. Aikman, B. Lupoli, D. J. Humphries, and D. E. Beever. 2003. Splanchnic metabolism of dairy cows during the transition from late gestation through early lactation. J. Dairy Sci. 86:1201-1217.

Røjen, B. A., P. Lund, and N. B. Kristensen. 2008. Urea and shortchain fatty acids metabolism in Holstein cows fed a low-nitrogen grass-based diet. Animal 2:500-513.

Schanbacher, F. L., and K. L. Smith. 1975. Formation and role of unusual whey proteins and enzymes: Relation to mammary function. J. Dairy Sci. 58:1048-1062. 